\title{
Application of Factorial Design and Desirability Function to Develop a Single Analytical Procedure for the Determination of Metals in Different Tissues of Blue Crab (Callinectes danae)
}

\author{
Daniel C. Lima, ${ }^{*, a}$ Wesley N. Guedes, ${ }^{a, b}$ Vinicius C. Costa ${ }^{a, c}$ and Fábio A. C. Amorim ${ }^{a}$ \\ ${ }^{a}$ Departamento de Ciências Exatas e Tecnológicas, Universidade Estadual de Santa Cruz, \\ 45662-900 Ilhéus-BA, Brazil \\ ${ }^{b}$ Departamento de Química Analítica, Instituto de Química, \\ Universidade Estadual Paulista (Unesp), 14800-060 Araraquara-SP, Brazil \\ ${ }^{c}$ Grupo de Análise Instrumental Aplicada (GAIA), Departamento de Química, \\ Universidade Federal de São Carlos (UFSCar), 13565-905 São Carlos-SP, Brazil
}

\begin{abstract}
In this scientific work, it was developed a single analytical procedure for the sample preparation of different tissues of blue crabs using microwave-assisted digestion for the determination of $\mathrm{Cu}$, $\mathrm{Mn}, \mathrm{Fe}$ and $\mathrm{Zn}$ by fast sequential flame atomic absorption spectrometry (FS FAAS). The limits of quatification were $10.5,1.6,8.9$ and $19.3 \mu \mathrm{g} \mathrm{g}^{-1}$ for $\mathrm{Cu}, \mathrm{Mn}, \mathrm{Fe}$ and $\mathrm{Zn}$, respectively. The precision was estimated in terms of repeatability using the relative standard deviation (RSD, $n=7) 3.4 \%$ for $\mathrm{Cu} ; 4.8 \%(\mathrm{Mn}) ; 4.7 \%(\mathrm{Fe})$ and $4.7 \%(\mathrm{Zn})$ and accuracy of the procedure was confirmed by analysis of certified reference material (CRM) of oyster tissue (NIST 1566B) with concentration values of 71.3 for $\mathrm{Cu}, 18.3$ for $\mathrm{Mn}, 202.5$ for $\mathrm{Fe}$ and $1415 \mu \mathrm{g} \mathrm{g}^{-1}$ for $\mathrm{Zn}$. The procedure has been applied for the determination of $\mathrm{Cu}, \mathrm{Mn}, \mathrm{Fe}$ and $\mathrm{Zn}$ in several blue crab samples from Cachoeira River estuary, Ilhéus, Bahia, Brazil.
\end{abstract}

Keywords: factorial design, desirability function, effect of matrix, singles analytical procedure

\section{Introduction}

Quantification of metals in different tissues of crustaceans has been receiving great importance, due to the information about the following items: relation to food quality control, indication of the environment where they live and extinction of some crustaceans species. ${ }^{1-4}$ However, there are three distinct groups of metals with relation to toxicity for living organisms: the first group is considered of low toxicity, which is considered as micronutrients, but in high concentrations, they are toxic. The elements that belong to this group are: iron, aluminum, cobalt, copper, manganese, molybdenum, selenium, vanadium, zinc and tin. The second group consists of metals with probability of cancer risk: beryllium, chromium and nickel. The third group has a significant toxic character and its members are not included in the previous groups: lead, cadmium, mercury and arsenic. These elements do not have any known physiological function for living organism so far. ${ }^{5-8}$

*e-mail: dclima@uesc.br
However, the determination of the elements of the above-mentioned groups is not always a simple task, and in this context the analytical method flame atomic absorption spectrometry (FAAS) shows itself as an excellent tool of determination mainly for its robustness. ${ }^{910}$ In addition, this method is consolidated and is widely used worldwide because of its simplicity, adequate sensitivity to determine several micro and macronutrients and have relatively low cost compared to other methods ${ }^{9}$ such as inductively coupled plasma optical emission spectrometry (ICP OES) and inductively coupled plasma mass spectrometry (ICP-MS).

On the other hand, the development of a single analytical procedure for the determination of chemistry species in different tissues of animal must consider the following factors: the difference of the concentration of analytes and equivalence in preparing sample of different tissues, because the residual solutions might have difference between physical and chemical properties and it could bring difference in the aspiration rates of sample introduction system of the instrument and cause systematic errors in the determination. ${ }^{11-16}$ 
The sequence of a development of an analytical procedure is first based on the choice of analytical method for the determination of chemical species, because it will determine the sample treatment. For example, there are several analytical instruments with different manners of sample introduction. In a device with introduction system by nebulization, the solid samples need a digestion step to become an aqueous solution and different matrices may require different treatments because they are different with relation to the amount of protein and lipids. Therefore, the residual solution will have physical and chemical properties, and differentiated aspiration rate by analytical instruments could feature a systematic error. ${ }^{17}$

The chemometrics is a statistical tool widely used to provide information regarding the concentration of the analytes in different samples, screening factors and mathematical modeling of analytical procedures with decrease of dimensionality to obtain information about interactions, cluster and others, but there are no scientific studies that blend into these chemometrics tools to prepare distinct diagnosis of samples with different matrices seeking a single condition for this purpose. ${ }^{18-22}$

In this context, this research had as goal the development of a single analytical procedure for the determination of $\mathrm{Cu}, \mathrm{Mn}, \mathrm{Fe}$ and $\mathrm{Zn}$ in different tissues of blue crab by fast sequential flame atomic absorption spectrometry (FS FAAS) applying factorial design and desirability function.

\section{Experimental}

Instrumentation

A flame atomic absorption spectrometer (Varian model SpectrAA 240FS, Mulgrave, Victoria, Australia) with fast sequential (FS) software equipped with an airacetylene burner was used for absorbance measurements. Hollow cathode lamps (Varian Instruments, Palo Alto, California, USA) were used as light sources in the respective wavelengths: $324.8(\mathrm{Cu}), 279.5(\mathrm{Mn}), 248.3(\mathrm{Fe})$ and $213.9 \mathrm{~nm}(\mathrm{Zn})$. Deuterium lamp background correction was also used. The flame composition was the mixture between acetylene (flow rate: $2.0 \mathrm{~L} \mathrm{~min}^{-1}$ ) and air (flow rate: 13.5 $\mathrm{L} \mathrm{min}^{-1}$ ). Sample aspiration rate was of $5.0 \mathrm{~mL} \mathrm{~min}^{-1}$.

A freeze-drying instrument, model L101 LIOTOP (São Carlos, São Paulo, Brazil), was used to lyophilize the samples. A ball mill model 8000 FL SHIMIDT (Spex Sample Prep, Metuchen, USA) was used for reducing the particles size. An analytical balance model BL D105 (Sartorius, Gottiengen, Germany) was used to establish the sample mass. The total digestion of the blue crab samples was carried out with a microwave oven closed-vessel model
MDS 40, Master Sineo equipped with 40 digestion tubes (Shanghai, China).

\section{Reagents and solutions}

All reagents were analytical reagent grade and the solutions were prepared using high-purity water that had a resistivity of $18.2 \mathrm{M} \Omega \mathrm{cm}$ obtained from a Milli-Q Plus water purification system from Millipore (Bedford, MA, USA). Nitric acid $\left(\mathrm{HNO}_{3}\right)\left(65 \%, \mathrm{~m} \mathrm{~m}^{-1}\right)$ and hydrogen peroxide $\left(\mathrm{H}_{2} \mathrm{O}_{2}\right)\left(30 \%, \mathrm{~m} \mathrm{~m}^{-1}\right)$ (Merck, Darmstadt, Germany) were used in total digestion. The analyte solutions used for external calibration were prepared from $1,000 \mathrm{mg} \mathrm{L}^{-1}$ standard solutions (Merck, Darmstadt, Germany). All laboratory glassware used were previously immersed in $\mathrm{HNO}_{3}$ solution $\left(10 \%, \mathrm{~m} \mathrm{~m}^{-1}\right)$ for $12 \mathrm{~h}$ for decontamination prior to use and then rinsed several times with deionized water.

\section{Sampling and preliminary treatment of the samples}

For the purpose of catching blue crabs in estuarine environment (in situ), it was used a trap with metal rim and a fishing net. A boat was used to move in the area to proceed sampling. The trap was put in seven points of the Cachoeira River estuary where 36 blue crabs were captured, used for optimization of the method, with biometrics range of 88.0 to $117.0 \mathrm{~mm}$. The animals were found between the following coordinates: from $(-14.807786,-39.040824)$ to $(-14.808461,-39.026431)$. In the laboratory, the muscles of the legs and claws were manually removed from the exoskeleton. Exoskeleton was broken with the support of a pistil and the soft tissues removed with the aid of an acrylic spatula. For the removal of the hepatopancreas, the ventral part of the exoskeleton was opened and with the aid of an acrylic spatula the tissue was removed.

Afterwards, in this process the total masses of each tissue were kept in Petri dishes separately, to be lyophilized. Following lyophilization, the samples were ground in a ball mill to reduce particle size and homogenize the tissues. Then the samples of the three tissues were kept in polypropylene bottles, previously decontaminated, and stored in a desiccator. The procedure developed was applied for the determination of $\mathrm{Cu}, \mathrm{Mn}, \mathrm{Fe}$ and $\mathrm{Zn}$ in the tissues of 47 blue crabs captured in three points along the Cachoeira River estuary, Ilhéus City. Figure 1 shows the total area where the sampling was done.

\section{Strategy for the procedure optimization}

For optimization, tissues of 36 animals were used and divided into three samples: claws muscles, legs muscles 


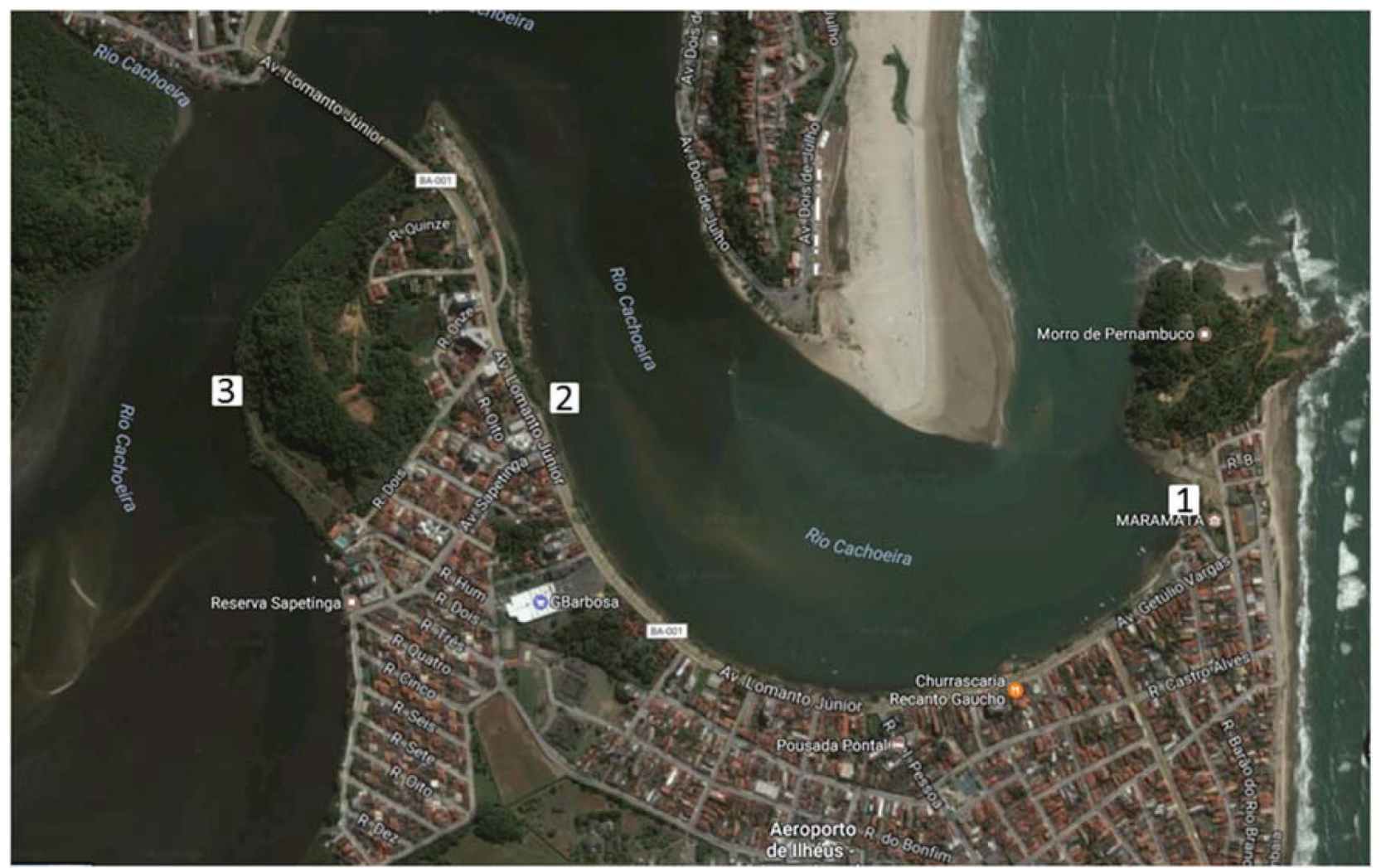

Figure 1. Location of the estuary and the sampling points of the application of the procedure.

and hepatopancreas. A full four-level factorial design $\left(2^{4}\right)$ was used in order to verify the influence and interactions of the following variables and levels: digestion time $(15,18$ and $21 \mathrm{~min})$, digestion temperature $\left(120,140\right.$ and $\left.160{ }^{\circ} \mathrm{C}\right)$, volume of $\mathrm{HNO}_{3}(1.0,2.0$ and $3.0 \mathrm{~mL})$ and volume of $\mathrm{H}_{2} \mathrm{O}_{2}(1.0,2.0$ and $3.0 \mathrm{~mL})$. The factorial design totalized 19 experiments, including three replicates at the central point.

Responses for experimental designs were obtained by evaluating the concentrations of the analytes studies after microwave-assisted digestion. The data analysis was performed using the software Statistica 8.0..$^{23}$ To allow simultaneous optimization of the responses obtained, a mathematical approach developed by Derringer and Suich ${ }^{24}$ was used. It is based on desirability functions applied in optimizing multi-response experiments. The approach first converts each response $\left(\mathrm{y}_{\mathrm{i}}\right)$ into an individual desirability function $\left(\mathrm{d}_{\mathrm{i}}\right)$, which varies within the range $0 \leq \mathrm{d}_{\mathrm{i}} \leq 1$. If the response is desired, $\mathrm{d}_{\mathrm{i}}=1$ and, if the response is outside the acceptable region, $d_{i}=0$. The individual desirability $\left(d_{i}\right)$ is calculated according to equation 1 :

$d=\left\{\begin{array}{l}0, \text { if } y<L \\ \left(\frac{y-L}{T-L}\right)^{s}, \text { if } L \leq y \leq T \\ 1, \text { if } y>T\end{array}\right.$ where $\mathrm{L}$ is the lowest acceptable value for the response, $\mathrm{T}$ is the target value and $\mathrm{s}$ is the weight (when equal to $1=$ linear desirability function). In this work, $\mathrm{L}$ values were the lowest concentration in a set of experiments for each element and $\mathrm{T}$ values were the highest concentration for each element.

The overall desirability (OD) is calculated according to equation 2 :

$\mathrm{OD}=\sqrt[m]{\mathrm{d}_{1} \mathrm{~d}_{2} \ldots \mathrm{d}_{\mathrm{m}}}$

where $\mathrm{m}$ is the number of response variables.

\section{Sample preparation}

\section{Microwave-assisted digestion}

Digestion was performed in triplicate according to the following procedure: $200 \mathrm{mg}$ of each sample was accurately weighed in digestion tubes and $1.0 \mathrm{~mL}$ of $\mathrm{HNO}_{3}\left(65 \%, \mathrm{~m} \mathrm{~m}^{-1}\right)$

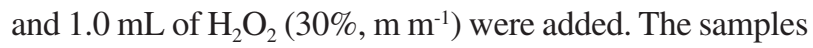
went through the total digestion process in a microwave oven with a cavity, under the heating program optimized as described: step 1: time of $10 \mathrm{~min}$, power 500 watts and temperature of $160{ }^{\circ} \mathrm{C}$; step 2: time of $21 \mathrm{~min}$, power 500 watts and temperature of $160{ }^{\circ} \mathrm{C}$. After this procedure, the digested were transferred to volumetric flask and the volumes were made up to $15.0 \mathrm{~mL}$ with ultrapure water. 
Validation and analytical features of the analytical procedure

The limit of detection (LOD) and the limit of quantification (LOQ) were determined according to International Union of Pure and Applied Chemistry (IUPAC) recommendations. ${ }^{25}$ Precision was estimated as the relative standard deviation ( $\mathrm{RSD}$, percentage). The accuracy of the procedure was confirmed by analysis of the certified reference material (CRM, Gaithersburg, MD, USA), oyster tissue NIST 1566 b.

\section{Results and Discussion}

\section{Optimization of the procedure}

Optimized conditions for acidic digestion, according to the $2^{4}$ factorial design, were performed to get a single analytical condition to prepare the samples of the different tissues of blue crabs by microwave-assisted digestion. In order to obtain a single condition to the factors of the digestion of all tissues, OD was used to join the different analytical responses of the different tissues, using a mathematical-statistical tool that is based on the use of a desirability function (D). This function was obtained using the concentrations of the analytes studies. Initially, it was realized a factorial design for each tissue and obtained an overall desirability in function of the concentrations of $\mathrm{Cu}, \mathrm{Mn}, \mathrm{Fe}$ and $\mathrm{Zn}$. Afterwards the obtainment of OD for each tissue, the same were utilizing to generate a single OD that allowed the utilization of a single step of digestion for all tissues.

After data processing, the evaluation of best conditions for digestion was performed by analysis of Pareto graphic, evaluating the significance of all factors and their interactions at a confidence level of $95 \%$. The magnitude of effects is represented by columns, and the vertical line indicates statistical significance at $p=0.05$, so the factors with values that exceed the vertical line are statistically significant at a confidence level of $95 \% .{ }^{26}$ Figure 2 shows the Pareto graphics for the tissues of claws muscles, legs muscles and hepatopancreas.

Pareto graphic obtained for the claws muscles (Figure 2a) shows that factors and their interactions are not significant inside this experimental domain. They did not influence the analytical response obtained in function of OD. However, the Pareto graphic obtained for legs muscles (Figure 2b) shows that the significant factor are digestion
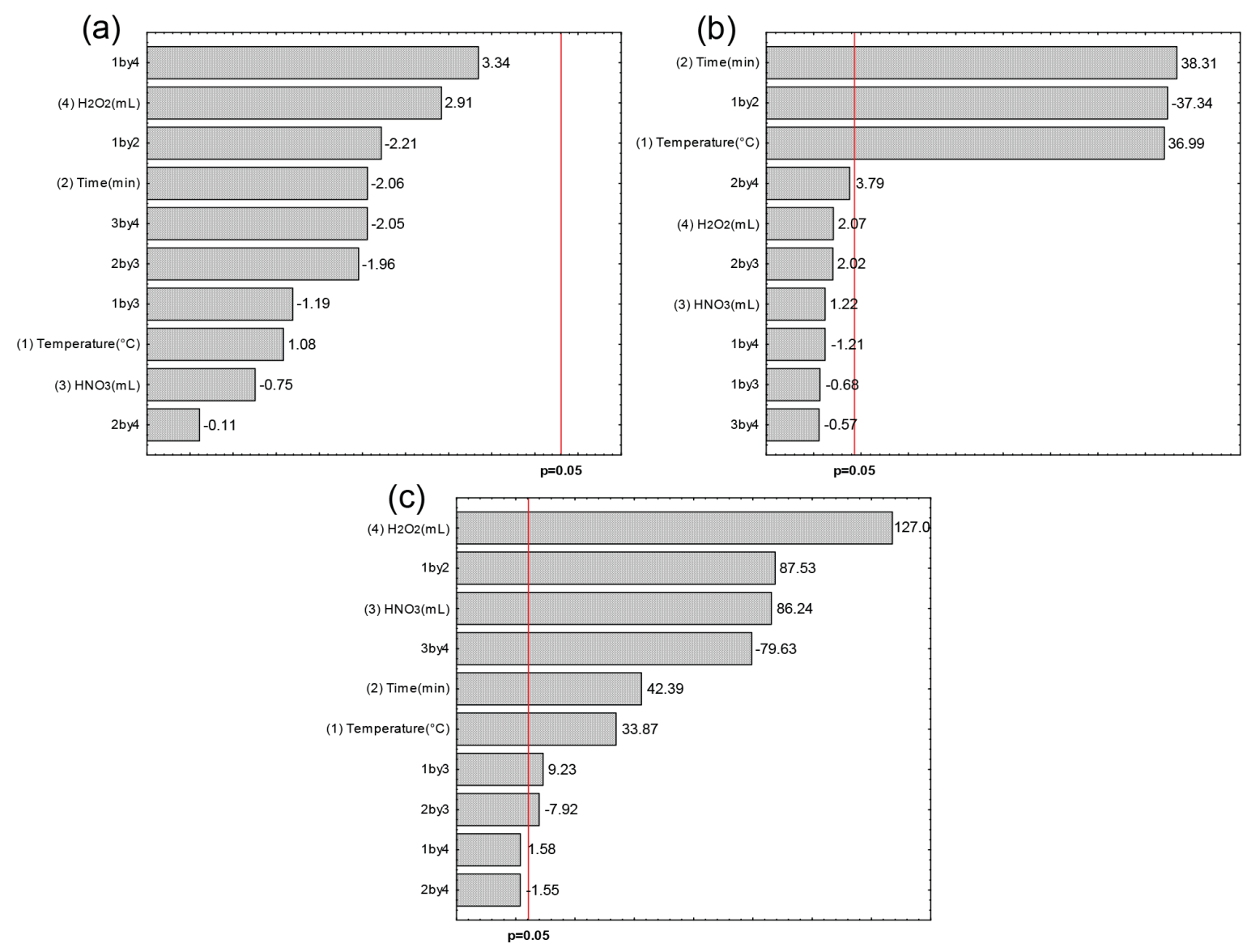

Figure 2. Pareto graphic of (a) claws muscles; (b) legs muscles and (c) hepatopancreas. 
time and temperature, as well as the interaction between them. On the other hand, the Pareto graphic obtained for the hepatopancreas (Figure 2c) shows that all factors were significant, as well as the interactions between: temperature with time, $\mathrm{HNO}_{3}$ with $\mathrm{H}_{2} \mathrm{O}_{2}$, temperature with $\mathrm{HNO}_{3}$ and time with $\mathrm{HNO}_{3}$.

According to the different profiles of the graphics of Pareto, it was observed that the hepatopancreas is the most complex of the tissues from blue crabs submitted to the procedure of digestion. The hepatopancreas tissue had the highest magnitude of the significant factors and their interaction for the analytical response among tissues, these factors are related to efficiency for the analytical procedure digestion. This can be explained by the fact that hepatopancreas has a high percentage of lipids, fatty acids, proteins and carbohydrates when compared to other tissues, thus making its decomposition more difficult. ${ }^{27,28}$ Therefore, the optimization considered only the desirability values (Table 1) of the tissues of the hepatopancreas and of the legs muscles.

The claws muscles tissue was disregarded for the new array of data because all factors and your interactions were not significant for the analytical response. The aim of the new array was to get a trend of a single condition of sample preparation for the different tissues. From the desirability, it was obtained the OD for each tissue, promoting an ideal and single condition for the three tissues. Figure 3 shows the graph of the desirability function obtained for the tissues of the legs muscles and hepatopancreas with optimized values. The optimized conditions for the microwave-assisted digestion were: temperature of $160^{\circ} \mathrm{C}$; time of $21 \mathrm{~min}, 1.0 \mathrm{~mL}$ of $\mathrm{HNO}_{3}$ and $1.0 \mathrm{~mL}$ of $\mathrm{H}_{2} \mathrm{O}_{2}$. As the volumes of $\mathrm{HNO}_{3}$ and $\mathrm{H}_{2} \mathrm{O}_{2}$ in the graphic of predicted values and desirability remained constant in the range of 1.0 to $3.0 \mathrm{~mL}$, it was opted the use of the minimum value of the experimental domain.

\section{Matrix effect}

Physical interference disturbs the phases of introduction of the sample, formation and transport of aerosol, size of drops, desolvation and volatilization, affecting the efficiency of nebulization and significantly the analytical response. This type of interference comes from the physicochemical characteristics of the matrix of the solution of samples as viscosity, the superficial tension and the tension of steam of the samples and the presence of organic compounds, which are directly related with the matrix of the residual digested. ${ }^{29}$

In order to check whether the matrix of the samples

Table 1. Experimental matrix with values of OD for the tissues of the legs muscles and hepatopancreas

\begin{tabular}{|c|c|c|c|c|c|c|}
\hline Experiment & Temperature $/{ }^{\circ} \mathrm{C}$ & time / min & $\mathrm{HNO}_{3} / \mathrm{mL}$ & $\mathrm{H}_{2} \mathrm{O}_{2} / \mathrm{mL}$ & OD legs & OD hepato \\
\hline 1 & $120(-1)$ & $15(-1)$ & $1(-1)$ & $1(-1)$ & 0.00 & 0.63 \\
\hline 2 & $160(+1)$ & $15(-1)$ & $1(-1)$ & $1(-1)$ & 0.75 & 0.00 \\
\hline 3 & $120(-1)$ & $21(+1)$ & $1(-1)$ & $1(-1)$ & 0.69 & 0.00 \\
\hline 4 & $160(+1)$ & $21(+1)$ & $1(-1)$ & $1(-1)$ & 0.69 & 0.73 \\
\hline 5 & $120(-1)$ & $15(-1)$ & $3(+1)$ & $1(-1)$ & 0.00 & 0.58 \\
\hline 6 & $160(+1)$ & $15(-1)$ & $3(+1)$ & $1(-1)$ & 0.74 & 0.56 \\
\hline 7 & $120(-1)$ & $21(+1)$ & $3(+1)$ & $1(-1)$ & 0.73 & 0.60 \\
\hline 8 & $160(+1)$ & $21(+1)$ & $3(+1)$ & $1(-1)$ & 0.73 & 0.74 \\
\hline 9 & $120(-1)$ & $15(-1)$ & $1(-1)$ & $3(+1)$ & 0.00 & 0.57 \\
\hline 10 & $160(+1)$ & $15(-1)$ & $1(-1)$ & $3(+1)$ & 0.72 & 0.69 \\
\hline 11 & $120(-1)$ & $21(+1)$ & $1(-1)$ & $3(+1)$ & 0.75 & 0.78 \\
\hline 12 & $160(+1)$ & $21(+1)$ & $1(-1)$ & $3(+1)$ & 0.75 & 0.73 \\
\hline 13 & $120(-1)$ & $15(-1)$ & $3(+1)$ & $3(+1)$ & 0.00 & 0.61 \\
\hline 14 & $160(+1)$ & $15(-1)$ & $3(+1)$ & $3(+1)$ & 0.70 & 0.78 \\
\hline 15 & $120(-1)$ & $21(+1)$ & $3(+1)$ & $3(+1)$ & 0.79 & 0.71 \\
\hline 16 & $160(+1)$ & $21(+1)$ & $3(+1)$ & $3(+1)$ & 0.77 & 0.72 \\
\hline 17 & $140(0)$ & $18(0)$ & $2(0)$ & $2(0)$ & 0.74 & 0.67 \\
\hline 18 & $140(0)$ & $18(0)$ & $2(0)$ & $2(0)$ & 0.71 & 0.66 \\
\hline 19 & $140(0)$ & $18(0)$ & $2(0)$ & $2(0)$ & 0.71 & 0.67 \\
\hline
\end{tabular}

OD: overall desirability; legs: legs muscles; hepato: hepatopancreas. 


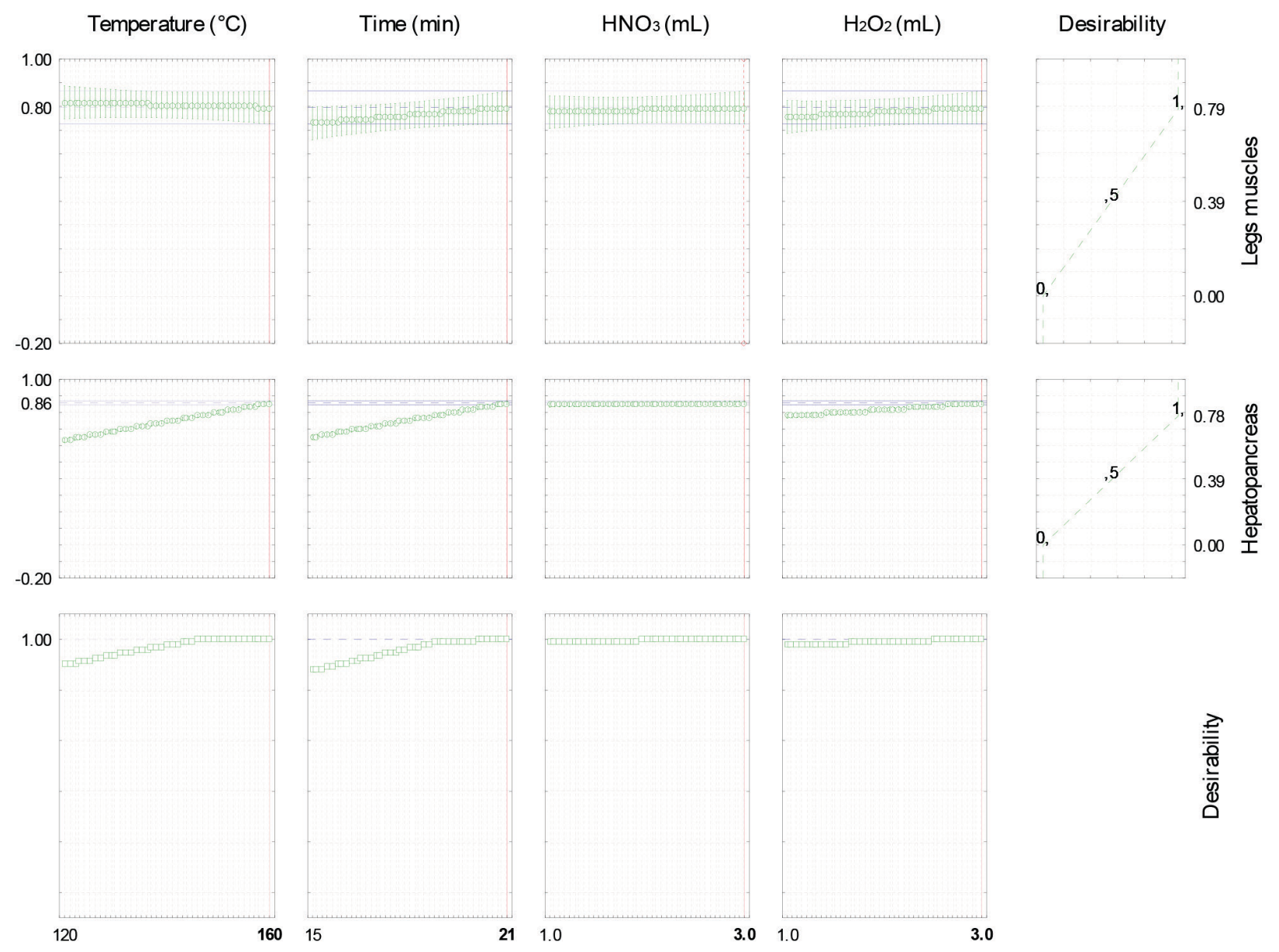

Figure 3. Graphic of profiles of predicted values and desirability for application of microwave digestion in the legs muscles and hepatopancreas.

interferes in determination of analyte, the aqueous calibration techniques, standard addition technique and calibration residual acidity were evaluated by statistics using analysis of variance (ANOVA) with significant difference at a $95 \%$ confidence level. Equations of the curve of calibration for the different conditions for each analyte and tissues are shown in Table 2.

Afterwards, the slopes of the curves were plotted applying, when appropriate, the hypothesis test $(\alpha=0.05) .{ }^{30}$ To evaluate the significant difference between the values of the angular coefficients of standard addition technique, significance tests $(\alpha=0.05)$ were applied. From those results, the matrix effect was analyzed for all calibration techniques. Considering the statistic test, it can report that there is no significant difference ( $\alpha=0.05$ ) between the analytical curves in the media studied, thus demonstrating that the matrix does not affect the determination of the elements and the calibration can be performed by any calibration techniques. Because of the simplicity, aqueous calibration method was used for the determination of analytes. For determination of the $\mathrm{Zn}$, the digests of all tissues needed to be diluted in the factor of 50 times to stay in the calibration linear range of analytical method, FS FAAS.

\section{Validation of the analytical procedure and analytical features}

The LOD and LOQ were calculated as the concentration of the analyte corresponding to three and ten times, respectively, the standard deviation of ten independent measurements of the analytical blank divided by the slope of the calibration curve. For the proposed procedure, LODs were: 3.2 for $\mathrm{Cu}$; 0.5 for $\mathrm{Mn}$; 2.7 for $\mathrm{Fe}$ and $5.8 \mu \mathrm{g} \mathrm{g} \mathrm{g}^{-1}$ for $\mathrm{Zn}$, and LOQs were: 10.5 for $\mathrm{Cu} ; 1.6$ for $\mathrm{Mn} ; 8.9$ for $\mathrm{Fe}$ and $19.3 \mu \mathrm{g} \mathrm{g}^{-1}$ for $\mathrm{Zn}$, and the precision, expressed in terms of repeatability using the relative standard deviation (RSD in percentage) for 7 digestions of the same sample with concentration of $\mathrm{Cu}\left(51.2 \mu \mathrm{g} \mathrm{g}^{-1}\right), \mathrm{Mn}\left(108.2 \mu \mathrm{g} \mathrm{g}^{-1}\right), \mathrm{Fe}$ $\left(245.2 \mu \mathrm{g} \mathrm{g}^{-1}\right)$ and $\mathrm{Zn}\left(92.1 \mu \mathrm{g} \mathrm{g}{ }^{-1}\right)$, was 3.4, 4.8, 4.7 and $4.7 \%$, respectively.

The accuracy values, which were evaluated by the analysis of the CRM of oyster tissue (NIST 1566b) and the results obtained considering the use of the proposed procedure, are presented in Table 3 . The statistical 
Table 2. Equations of the calibration curves obtained in aqueous, residual acidity and standard addition technique for the determination of $\mathrm{Cu}, \mathrm{Mn}, \mathrm{Fe}$ and $\mathrm{Zn}$ in tissues samples

\begin{tabular}{|c|c|c|c|c|}
\hline Analyte & Mean & Calibration technique & Equation & $\mathrm{R}^{2}$ \\
\hline \multirow{5}{*}{$\mathrm{Cu}$} & aqueous & conventional & $\mathrm{y}=(0.1020 \pm 0.0018) \mathrm{C}_{\mathrm{Cu}}+(0.0028 \pm 0.0037)$ & 0.9998 \\
\hline & acidic & residual acidity & $\mathrm{y}=(0.1007 \pm 0.0014) \mathrm{C}_{\mathrm{Cu}}+(0.0037 \pm 0.0028)$ & 0.9999 \\
\hline & hepato $^{a}$ & st. add. techn. & $\mathrm{y}=(0.1002 \pm 0.0015) \mathrm{C}_{\mathrm{Cu}}+(0.0647 \pm 0.0032)$ & 0.9998 \\
\hline & claws $^{\mathrm{b}}$ & st. add. techn. & $\mathrm{y}=(0.1026 \pm 0.0024) \mathrm{C}_{\mathrm{Cu}}+(0.0223 \pm 0.0050)$ & 0.9996 \\
\hline & $\operatorname{legs}^{\mathrm{c}}$ & st. add. techn. & $\mathrm{y}=(0.1000 \pm 0.0015) \mathrm{C}_{\mathrm{Cu}}+(0.0303 \pm 0.0030)$ & 0.9998 \\
\hline \multirow{5}{*}{$\mathrm{Mn}$} & aqueous & conventional & $\mathrm{y}=(0.1517 \pm 0.0035) \mathrm{C}_{\mathrm{Mn}}+(0.0026 \pm 0.0041)$ & 0.9996 \\
\hline & acidic & residual acidity & $\mathrm{y}=(0.1528 \pm 0.0034) \mathrm{C}_{\mathrm{Mn}}+(0.0020 \pm 0.0039)$ & 0.9996 \\
\hline & hepato & st. add. techn. & $\mathrm{y}=(0.1526 \pm 0.0029) \mathrm{C}_{\mathrm{Mn}}+(0.0343 \pm 0.0034)$ & 0.9997 \\
\hline & claws & st. add. techn. & $\mathrm{y}=(0.1516 \pm 0.0026) C_{\mathrm{Mn}}+(0.0033 \pm 0.0030)$ & 0.9998 \\
\hline & legs & st. add. techn. & $\mathrm{y}=(0.1536 \pm 0.0032) C_{\mathrm{Mn}}+(0.0028 \pm 0.0037)$ & 0.9997 \\
\hline \multirow{5}{*}{$\mathrm{Fe}$} & aqueous & conventional & $\mathrm{y}=(0.0513 \pm 0.0007) C_{\mathrm{Fe}}+(0.0095 \pm 0.0015)$ & 0.9999 \\
\hline & acidic & residual acidity & $\mathrm{y}=(0.0507 \pm 0.0017) \mathrm{C}_{\mathrm{Fe}}+(0.0055 \pm 0.0035)$ & 0.9992 \\
\hline & hepato & st. add. techn. & $\mathrm{y}=(0.0517 \pm 0.0019) \mathrm{C}_{\mathrm{Fe}}+(0.0139 \pm 0.0039)$ & 0.9990 \\
\hline & claws & st. add. techn. & $\mathrm{y}=(0.0515 \pm 0.0019) \mathrm{C}_{\mathrm{Fe}}+(0.0089 \pm 0.0039)$ & 0.9990 \\
\hline & legs & st. add. techn. & $\mathrm{y}=(0.0513 \pm 0.0013) \mathrm{C}_{\mathrm{Fe}}+(0.0062 \pm 0.0026)$ & 0.9995 \\
\hline \multirow{5}{*}{$\mathrm{Zn}$} & aqueous & conventional & $\mathrm{y}=(0.2126 \pm 0.0056) \mathrm{C}_{\mathrm{Zn}}+(0.0042 \pm 0.0034)$ & 0.9995 \\
\hline & acidic & residual acidity & $y=(0.2086 \pm 0.0056) C_{z n}+(0.0076 \pm 0.0035)$ & 0.9994 \\
\hline & hepato & st. add. techn. & $\mathrm{y}=(0.2124 \pm 0.0074) \mathrm{C}_{\mathrm{Zn}}+(0.0370 \pm 0.0046)$ & 0.9991 \\
\hline & claws & st. add. techn. & $\mathrm{y}=(0.2041 \pm 0.0067) C_{\mathrm{Zn}}+(0.0383 \pm 0.0041)$ & 0.9992 \\
\hline & legs & st. add. techn. & $\mathrm{y}=(0.2044 \pm 0.0055) C_{\mathrm{Zn}}+(0.0401 \pm 0.0034)$ & 0.9994 \\
\hline
\end{tabular}

aHepato: hepatopancreas; ${ }^{\text {c}}$ laws muscles; 'legs: legs muscles; $\mathrm{R}^{2}$ : coefficient of determination; st. add. techn.: standard addition technique.

evaluation using the expanded uncertainty proved that there is no significant difference in the level of $95 \%$ of confidence between the values obtained with the proposed procedure and the reference values.

Table 3. Comparison of the value obtained through the proposed procedure with the certified value for CRM oyster tissue NIST 1566B (average \pm confidence interval, $\mathrm{n}=3$ )

\begin{tabular}{|c|c|c|c|}
\hline \multirow{2}{*}{ Analyte } & \multicolumn{2}{|c|}{ Concentration / $\left(\mu \mathrm{g} \mathrm{g}^{-1}\right)$} & \multirow{2}{*}{$\begin{array}{c}\text { Test CRM } \\
\text { (expanded } \\
\text { uncertainty) }\end{array}$} \\
\hline & Certified value & Proposed procedure & \\
\hline $\mathrm{Cu}$ & $71.6 \pm 1.6$ & $71.3 \pm 2.3$ & $0.3 \leq 2.89$ \\
\hline $\mathrm{Mn}$ & $18.5 \pm 0.2$ & $18.3 \pm 0.9$ & $0.2 \leq 1.13$ \\
\hline $\mathrm{Fe}$ & $205.8 \pm 6.8$ & $202.5 \pm 2.5$ & $1.4 \leq 5.19$ \\
\hline $\mathrm{Zn}$ & $1424 \pm 46$ & $1415 \pm 36$ & $9.0 \leq 51.04$ \\
\hline
\end{tabular}

CRM: certified reference material.

\section{Application}

The proposed procedure was applied in determination of $\mathrm{Cu}, \mathrm{Mn}, \mathrm{Fe}$ and $\mathrm{Zn}$ in the tissues samples of 47 blue crabs captured in three points around the Cachoeira River estuary (Figure 1), in Ilhéus City, Bahia, Brazil. The coordinates of the location of sampling points were obtained from the
Global Positioning System (GPS). At point 1 (-14.811308, $-39.028705) 12$ animals with biometrics between $7.8-11.0 \mathrm{~cm}$ were captured, at point $2(-14.807113,-39.036143)$ 25 animals with biometrics between 8.1-13.1 cm were captured and at point $3(-14.807010,-39.041157) 10$ animals with biometrics between 7.6-10.8 $\mathrm{cm}$ were captured. The tissues of the animals were divided into claws muscles, legs muscles and hepatopancreas. After this process, these tissues were lyophilized and homogenized with balls mill, obtaining three batches of mass of each one of the tissues. This process was repeated for each one of the 3 sampling points. Then, seven replicates with mass of $0.2000 \mathrm{~g}$ were withdrawn from each batch to perform the total digestion in microwave oven. $\mathrm{The} \mathrm{Cu}, \mathrm{Mn}, \mathrm{Fe}$ and $\mathrm{Zn}$ concentrations were determined by FS FAAS and the values are shown in Table 4.

Other works found in literature already reported the determination of $\mathrm{Cu}, \mathrm{Mn}, \mathrm{Fe}$ and $\mathrm{Zn}$ in muscles and hepatopancreas of blue crabs. Türkmen et al., ${ }^{31}$ at the Northern Skenderun Bay, East Mediterranean, determined the concentrations of $\mathrm{Cu}, \mathrm{Mn}, \mathrm{Fe}$ and $\mathrm{Zn}$ in the muscles of $C$. sapidus. The concentrations of $\mathrm{Cu}$ and $\mathrm{Mn}$ were similar to present study, but the concentration of $\mathrm{Fe}$ was higher than the $\mathrm{Zn}$. Similar result was reported in the work 
Table 4. Concentration range for $\mathrm{Cu}, \mathrm{Fe}, \mathrm{Mn}$ and $\mathrm{Zn}$, in the three studied blue crab tissues, in the respective sampling points

\begin{tabular}{|c|c|c|c|c|c|c|c|c|c|c|c|c|}
\hline \multirow{3}{*}{ Sample } & \multicolumn{4}{|c|}{$\begin{array}{c}\text { Point } 1 \\
(\mathrm{n}=12 \text { animals })\end{array}$} & \multicolumn{4}{|c|}{$\begin{array}{c}\text { Point } 2 \\
(\mathrm{n}=25 \text { animals })\end{array}$} & \multicolumn{4}{|c|}{$\begin{array}{c}\text { Point } 3 \\
(\mathrm{n}=10 \text { animals })\end{array}$} \\
\hline & \multicolumn{4}{|c|}{ Concentration / $\left(\mu \mathrm{g} \mathrm{g}^{-1}\right)$} & \multicolumn{4}{|c|}{ Concentration / $\left(\mu \mathrm{g} \mathrm{g}^{-1}\right)$} & \multicolumn{4}{|c|}{ Concentration / $\left(\mu \mathrm{g} \mathrm{g}^{-1}\right)$} \\
\hline & $\mathrm{Cu}$ & $\mathrm{Mn}$ & $\mathrm{Fe}$ & $\mathrm{Zn}$ & $\mathrm{Cu}$ & $\mathrm{Mn}$ & $\mathrm{Fe}$ & $\mathrm{Zn}$ & $\mathrm{Cu}$ & $\mathrm{Mn}$ & $\mathrm{Fe}$ & $\mathrm{Zn}$ \\
\hline \multirow{7}{*}{$\begin{array}{l}\text { Claws muscles } \\
\text { ( } 7 \text { replicates) }\end{array}$} & 47.8 & 2.49 & 18.1 & 940 & 56.7 & 4.53 & 10.7 & 956 & 39.0 & 2.04 & 14.0 & 913 \\
\hline & 50.9 & 2.71 & 16.2 & 925 & 57.5 & 4.58 & 10.1 & 963 & 38.9 & 1.97 & 14.4 & 903 \\
\hline & 50.5 & 2.41 & 16.7 & 926 & 58.7 & 4.44 & 10.7 & 975 & 37.3 & 2.04 & 13.8 & 896 \\
\hline & 49.4 & 2.21 & 17.9 & 946 & 59.3 & 4.10 & 10.8 & 979 & 36.6 & 2.02 & 12.9 & 923 \\
\hline & 48.4 & 2.59 & 16.2 & 941 & 54.5 & 4.03 & 11.9 & 993 & 37.5 & 1.95 & 12.9 & 917 \\
\hline & 50.6 & 2.10 & 16.2 & 949 & 55.1 & 4.12 & 10.4 & 995 & 37.0 & 2.05 & 14.3 & 940 \\
\hline & 50.5 & 2.54 & 16.2 & 954 & 55.0 & 4.49 & 10.0 & 957 & 41.6 & 2.22 & 13.9 & 933 \\
\hline \multirow{7}{*}{$\begin{array}{l}\text { Legs muscles } \\
\text { (7 replicates) }\end{array}$} & 61.2 & 3.27 & 56.3 & 830 & 69.8 & 5.47 & 30.9 & 853 & 42.3 & 5.10 & 74.7 & 852 \\
\hline & 61.8 & 3.17 & 54.1 & 830 & 69.7 & 5.37 & 31.0 & 863 & 42.4 & 4.75 & 75.0 & 855 \\
\hline & 61.2 & 3.45 & 52.2 & 807 & 69.7 & 5.29 & 30.7 & 865 & 42.9 & 4.99 & 71.5 & 857 \\
\hline & 60.7 & 3.65 & 52.2 & 838 & 69.6 & 4.96 & 29.7 & 865 & 43.4 & 4.99 & 72.4 & 885 \\
\hline & 66.3 & 3.65 & 51.9 & 841 & 69.7 & 5.42 & 29.9 & 868 & 43.5 & 4.75 & 70.8 & 889 \\
\hline & 65.0 & 3.26 & 52.4 & 841 & 69.1 & 5.00 & 29.5 & 865 & 42.0 & 5.13 & 72.8 & 849 \\
\hline & 64.9 & 3.89 & 50.9 & 839 & 69.7 & 4.90 & 29.3 & 859 & 45.4 & 5.42 & 73.2 & 849 \\
\hline \multirow{7}{*}{$\begin{array}{l}\text { Hepatopancreas } \\
\text { ( } 7 \text { replicates) }\end{array}$} & 157 & 13.9 & 117 & 750 & 234 & 11.0 & 94.9 & 653 & 88.4 & 16.5 & 128 & 554 \\
\hline & 163 & 12.2 & 124 & 775 & 234 & 10.9 & 93.8 & 657 & 89.1 & 16.2 & 126 & 559 \\
\hline & 165 & 11.9 & 123 & 771 & 239 & 11.0 & 94.4 & 664 & 93.0 & 16.4 & 129 & 566 \\
\hline & 165 & 12.6 & 132 & 777 & 235 & 10.6 & 91.8 & 649 & 91.2 & 15.5 & 124 & 551 \\
\hline & 163 & 11.6 & 130 & 778 & 232 & 11.6 & 90.8 & 658 & 90.5 & 15.4 & 124 & 550 \\
\hline & 163 & 12.2 & 125 & 776 & 239 & 10.8 & 93.5 & 656 & 96.1 & 16.8 & 120 & 555 \\
\hline & 153 & 12.5 & 124 & 775 & 247 & 10.6 & 89.4 & 652 & 84.5 & 14.7 & 119 & 531 \\
\hline
\end{tabular}

of Mutlu et al. ${ }^{32}$ for the concentrations of $\mathrm{Cu}, \mathrm{Mn}, \mathrm{Fe}$ and $\mathrm{Zn}$ in muscles of $C$. sapidus at Mediterranean Lagoons, Turkey, finding the concentration of Fe higher than the concentration of $\mathrm{Zn}$. These results differ from the present study, which found the concentration of $\mathrm{Zn}$ higher than the concentrations of $\mathrm{Cu}, \mathrm{Mn}$ and $\mathrm{Fe}$ in the claws muscles, legs muscles and in the hepatopancreas, which is in agreement with several authors.

In the work of Bordon et al.,$^{33}$ it was determined the concentrations of $\mathrm{Cu}, \mathrm{Mn}, \mathrm{Fe}$ and $\mathrm{Zn}$ in muscles of C. danae in Santos Estuarine System, São Paulo State, Brazil. In this study, the concetrations of $\mathrm{Zn}$ were higher than the concentrations of $\mathrm{Cu}, \mathrm{Mn}$ and $\mathrm{Fe}$. In another study of Bordon et al. ${ }^{34}$ the concentrations of $\mathrm{Fe}$ and $\mathrm{Zn}$ in muscles and hepatopancreas were determined and also it was obtained higher concentrations of $\mathrm{Zn}$ compared to the concentrations of $\mathrm{Fe}$. Andrade et al. ${ }^{35}$ also determined $\mathrm{Cu}$, $\mathrm{Fe}$ and $\mathrm{Zn}$ in C. ornatus in Lagoa de Iquiparí, RJ, Brazil, being the values of concentrations of $\mathrm{Zn}$ higher than the concentrations of $\mathrm{Cu}$ and $\mathrm{Fe}$.

Recent works also show uniformity with the present study. Lavradas et al. ${ }^{3}$ determined the concentrations of $\mathrm{Cu}$ and $\mathrm{Zn}$ in muscles and hepatopancreas of $C$. sapidus in Ilha Grande Bay, Rio de Janeiro, Brazil and obtained concentrations of $\mathrm{Zn}$ higher than the concentrations of $\mathrm{Fe}$, as well as the work of Genç and Yilmaz ${ }^{36}$ that determined $\mathrm{Cu}, \mathrm{Mn}, \mathrm{Fe}$ and $\mathrm{Zn}$ in the muscles and hepatopancreas of C. sapidus in the estuary of Koycegiz Lake, South-West, Turkey, obtaining concentrations of $\mathrm{Zn}$ higher than the concentrations of $\mathrm{Cu}, \mathrm{Mn}$ and $\mathrm{Fe}$, corroborating with the results found in the present study.

\section{Conclusions}

Multivariate optimization using the full-four level factorial design $\left(2^{4}\right)$ and desirability function, made it possible to obtain a single condition (instrumental and chemical) that enabled the simultaneous microwaveassisted decomposition for the three crab tissues and hepatopancreas samples as the most complex matrix among the evaluated tissues. The optimized conditions for the microwave-assisted digestion were: temperature of $160^{\circ} \mathrm{C}$, time of $21 \mathrm{~min}, 1.0 \mathrm{~mL}$ of $\mathrm{HNO}_{3}$ and $1.0 \mathrm{~mL}$ of $\mathrm{H}_{2} \mathrm{O}_{2}$.

Main advantage of this analytical procedure was getting a single procedure to decompose three tissues (claws muscle, legs muscle and hepatopancreas) of blue crabs 
being a complex study to determine chemistry species in different samples with difference among physical and chemistry features. These results confirm the great feasibility of applying this procedure for the determination of $\mathrm{Cu}, \mathrm{Mn}, \mathrm{Fe}$ and $\mathrm{Zn}$ in blue crabs captured around the Cachoeira River estuary, which may cover other studies in different science areas.

\section{Acknowledgments}

Authors acknowledge the financial support of Fundação de Amparo à Pesquisa do Estado da Bahia (FAPESB, PET0025/2012), Conselho Nacional de Desenvolvimento Científico e Tecnológico (CNPq), Coordenação de Aperfeiçoamento de Pessoal de Nível Superior (CAPES), Financiadora de Estudos e Projetos (FINEP) and Santa Cruz State University (UESC, 0220.1100.899).

\section{References}

1. Zhou, Q.; Zhang, J.; Fu, J.; Shi, J.; Jiang, G.; Anal. Chim. Acta 2008, 606, 135.

2. Cherkashin, S. A.; Blinova, N. K.; Hydrobiol. J. 2008, 44, 89.

3. Lavradas, R. T.; Hauser-Davis, R. A.; Lavandier, R. C.; Rocha, R. C. C.; Saint'Pierre, T. D.; Seixas, S.; Kehrig, H. A.; Moreira, I.; Ecotoxicol. Environ. Saf. 2014, 107, 55.

4. Adams, D. H.; Engel, M. E.; Ecotoxicol. Environ. Saf. 2014, 102, 196.

5. Yedjou, G. C.; Tchounwou, P. B.; Int. J. Environ. Res. 2008, 4, 132.

6. Tchounwou, P. B.; Ishaque, A.; Schneider, J.; Mol. Cell. Biochem. 2001, 222, 21.

7. Sutton, D.; Tchounwou, P. B.; Ninashvili, N.; Shen, E.; Int. J. Environ. Res. 2002, 3, 965.

8. Tchounwou, P. B.; Centeno, J. A.; Patlolla, A. K.; Mol. Cell. Biochem. 2004, 255, 47.

9. Amorim, F. A. C.; Lobo, I. P.; Santos, V. L. C. S.; Ferreira, S. L. C.; Quim. Nova 2008, 31, 1784.

10. Amorim, F. A. C.; Costa, V. C.; Guedes, W. N.; Sá, I. P.; Santos, M. C.; Silva, E. G. P.; Castro, D. C.; Food Anal. Methods 2016, 9, 1719.

11. Santos, W. P. C.; Hatje, V.; Santil, D. S.; Fernandes, A. P.; Korn, M. G. A.; Souza, M. M.; Microchem. J. 2010, 95, 169.

12. Raposo, J. C.; Villanueva, U.; Bartolomé, L.; Olivares, M.; Carrero, J. A.; Sarmiento, A.; Etxebarria, N.; Madariaga, J. M.; Microchem. J. 2011, 99, 252.

13. Weber, P.; Behr, E. R.; Knorr, C. L.; Vendruscolo, D. S.; Flores, E. M. M.; Dressler, V. L.; Baldisserotto, B.; Microchem. J. 2013, 106, 61.

14. Schenone, N. F.; Avigliano, E.; Goessler, W.; Cirelli, A. F.; Microchem. J. 2014, 112, 127.
15. Macedo, G. R.; Tarantino, T. B.; Barbosa, I. S.; Pires, T. T.; Rostan, G.; Goldberg, D. W.; Pinto, L. F. B.; Korn, M. G. A.; Franke, C. R.; Mar. Pollut. Bull. 2015, 94, 284.

16. Ferreira, K. S.; Ferreira, W. A.; Gomes, J. M. M.; Correa-Júnior, J. D.; Donnici, C. L.; Silva, J. B. B.; Microchem. J. 2016, 124, 350.

17. Korn, M. G. A.; Morte, E. S. B.; Santos, D. C. M. B.; Castro, J. T.; Barbosa, J. T. P.; Teixeira, A. P.; Fernandes, A. P.; Welz, B.; Santos, W. P. C.; Santos, E. B. G. N.; Korn, M.; Appl. Spectrosc. Rev. 2008, 43, 67.

18. Ferreira, S. L. C.; Korn, M. G. A.; Ferreira, H. S.; Silva, E. G. P.; Araujo, R. G. O.; Souza, A. S.; Macedo, S. M.; Lima, D. C.; Jesus, R. M.; Amorim, F. A. C.; Sendra, J. M. B.; Appl. Spectrosc. Rev. 2007, 42, 475.

19. Santos, W. P. C.; Castro, J. T.; Bezerra, M. A.; Fernandes, A. P.; Ferreira, S. L. C.; Korn, M. G. A.; Microchem. J. 2009, 91, 153.

20. Leardi, R.; Anal. Chim. Acta 2009, 652, 161.

21. Amorim, F. A. C.; Costa, V. C.; Silva, E. G. P.; Castro, D. L.; Jesus, R. M.; Bezerra, M. A.; Food Chem. 2017, 227, 41.

22. Bezerra, M. A.; Santos, Q. O.; Santos, A. G.; Novaes, C. G.; Ferreira, S. L. C.; Souza, V. S.; Microchem. J. 2016, 124, 45.

23. Statistica 8.0, Statsoft, Tulsa, USA, 2007.

24. Derringer, G.; Suich, R.; J. Qual. Technol. 1980, 12, 214.

25. Thompson, M.; Ellison, S. L. R.; Wood, R.; Pure Appl. Chem. 2002, 74, 835.

26. Costa, S. S. L.; Pereira, A. C. L.; Passos, E. A.; Alves, J. P. H.; Garcia, C. A. B.; Araujo, R. G. O.; Talanta 2013, 108, 157.

27. Freire, C. A.; Togni, V. G.; Hermes-Lima, M.; Comp. Biochem. Physiol., Part A: Mol. Integr. Physiol. 2011, 160, 291.

28. Latyshev, N. A.; Kasyanov, S. P.; Kharlamenko, V. I.; Svetashev, V. I.; Food Chem. 2009, 116, 657.

29. Welz, B.; Sperling, M.; Atomic Absorption Spectrometry, $3^{\text {rd }}$ ed.; Wiley-VCH: Weinheim, Germany, 1999.

30. Miller, J. N.; Miller, J. C.; Statistics and Chemometrics for Analytical Chemistry, $6^{\text {th }}$ ed.; Pearson: Harlow, UK, 2010, p. 297.

31. Türkmen, A.; Türkmen, M.; Tepe, Y.; Mazlum, Y.; Oymael, S.; Bull. Environ. Contam. Toxicol. 2006, 77, 186.

32. Mutlu, C.; Türkmen, M.; Türkmen, A.; Tepe, Y.; Bull. Environ. Contam. Toxicol. 2011, 87, 282.

33. Bordon, I. C. A. C.; Sarkis, J. E. S.; Tomás, A. R. G.; Scalco, A.; Lima, M.; Hortellani, M. A.; Andrade, N. P.; Bull. Environ. Contam. Toxicol. 2012, 89, 484.

34. Bordon, I. C. A. C.; Sarkis, J. E. S.; Tomás, A. R. G.; Souza, M. R.; Scalco, A.; Lima, M.; Hortellani, M. A.; Bull. Environ. Contam. Toxicol. 2012, 88, 577.

35. Andrade, S. F.; Matos, T. B.; de Carvalho, C. E. V.; Rev. Virtual Quim. 2011, 3, 129.

36. Genç, T. O.; Yilmaz, F.; Indian J. Anim. Sci. 2015, 85, 94. 